Ethiopian Journal of Environmental Studies \& Management 7(1): 96 - 103, 2014

ISSN:1998-0507

doi: http://dx.doi.org/10.4314/ejesm.v7i1.12

Submitted: November 19, 2013

Accepted: February 6, 2014

\title{
KNOWLEDGE LEVELS OF EXTENSION AGENTS AND THEIR PERCEIVED IMPACT OF CLIMATE CHANGE ON EXTENSION SERVICE PROVISION IN GHANA
}

*OGUNLADE, I., ${ }^{1}$ ADERINOYE-ABDULWAHAB, S. A. ${ }^{1}$ AND MENSAH, A. $0 .{ }^{2}$

${ }^{1}$ Department of Agricultural Extension and Rural Development, University of Ilorin, Nigeria.

${ }^{2}$ Department of Agricultural Economics and Extension, University of Cape Coast, Ghana

\begin{abstract}
This study examined the knowledge levels of extension agents and their perceived impact of climate change on extension service provision in Ghana. Specifically, it examined awareness levels of agents on the causes, effects and methods for mitigating climate change. It also determined their perceived impact of climate on extension service delivery. A structured questionnaire was used to elicit information from a sample size of 192 respondents from 10 regions in Ghana who were randomly selected. The data were analyzed using frequency, percentages, mean, and standard deviation. Data was further analysed qualitatively by content analysis given the prevalent use of Likert type scale analyses. The findings showed that majority of the respondents were males within the age range of 40 to 49 years, married with above $15 y e a r s$ work experience in extension service provision. They possessed high awareness of the concept climate change, and need for farmers to be exposed to new technology. The study concluded that extension workers have to be abreast of innovations in agriculture and there is a need for incorporation of meteorological information in extension messages to farmers. It was recommended that extension agents should embrace a more innovative and participatory approaches of providing services.
\end{abstract}

\section{Introduction}

Agriculture is the mainstay of the Ghanaian economy and provides for the livelihood of $70 \%$ of the population. It contributes $39 \%$ to Gross domestic Product (GDP) of the country, which was estimated at $\mathrm{GH} \phi 11.6$ billion in 2006 (ISSER, 2007). Agriculture plays an important role in the country's economic growth, food security, poverty reduction, livelihoods, rural development and the environment (Dorward et al., 2004). Growth in the agricultural sector stimulates higher rates of growth in the economy through forward linkage activities such as processing and transportation, and backward linkages like the provision of services to the sector. Further growth is spurred as a result of spending incomes earned from all these productive activities (MoEFRN, 2003). However, climate change has been a major challenge to agricultural development in Ghana as increased body of evidence shows that climatic variability is adversely affecting natural resources such as land, water, forests and vegetation. Food security is also under threat from unpredictable changes in rainfall and more frequent extreme weather conditions.
Recent statistics show that a total of 1.2 million Ghanaians are with limited access to sufficient and nutritious food throughout the year. Another 2 million are at risk of insufficient access, becoming food insecure during the lean season, or a natural or manmade disaster. These figures constitute between 5 to $10 \%$ of the total population, but the majority of people at risk of food insecurity are concentrated in the three northern regionsNorthern, Upper East and Upper West Regions (MoEFRN, 2003). Events such as the severe floods and drought of 2007, coupled with climate change impacts, chieftaincy conflicts, rise in global food and fuel prices have cumulatively heightened the already existing vulnerabilities among people and communities in these regions.

Ziervogel et al. (2006) noted that climate change, which is attributable to natural climate cycle and human activities, has adversely affected agricultural productivity in Africa as a whole. This is particularly because African agriculture is predominantly rain-fed and hence fundamentally dependent on the vagaries of weather (UNFCCC, 2007). Zoellick (2009) stated that, as the planet warms, rain fall

*Corresponding Author: Ogunlade, I. Email: iogunlade@yahoo.com 
patterns shift and extreme events such as droughts, floods, and forest fires become more frequent. This results in poor and unpredictable yields, thereby making farmers more environmentally and socio-economically vulnerable and this is particularly true for Africa (UNFCCC, 2007). Climate change affects agriculture in several ways, one of which is its direct impact on food production. Besides, almost all sectors in agriculture (crop, livestock, pastoralism, and fishery) depend on weather and climate whose variability have meant that rural farmers who implement their regular annual farm business plans risk total failure due to climate change effects (Ozor et al., 2010). The risk from climate includes; rising temperatures and heat waves, shortfalls in water supply/increasing floods arising from shortage/excessive rainfalls, sea level rise, increasing likelihood of conflict and induced environmental and vector borne diseases (Ziervogel et al., 2006; Tologbonse et al., 2010). These conditions emanating from climate change impact are bound to compromise agricultural productions (crop, livestock, forest and fishery resources), nutritional and health status, trading in agricultural commodities, human settlements (especially of agricultural communities), tourism and recreation among others (Tologbonse et al., 2010).

The role of extension system as a means of providing information and new technologies and to farmers in order to enable them combat the menace of climatic change is however documented and universally acknowledged. Agricultural extension, according to Leeuwis and Aarts (2011), is a series of embedded communicative interventions that are meant, among other things, to develop and/or induce innovations. Such innovations supposedly help to resolve (usually multi-sector) problematic situations. It has been observed that agricultural extension is involved in public information and education programs that could assist farmers in mitigating the effects of climate change (MoEFRN, 2003). Such involvements include awareness creation and knowledge brokerage on the issues of climate change (Ziervogel et al., 2006). The involvement also includes building resilient capacities among vulnerable individuals, communities and regions. Encouragement of wide participation of all stakeholders and developing appropriate frameworks for coping/adaptation could also help to mitigate the effects/impacts of climate change. A good extension service should be able to provide information about new and better technologies that solve particular constraints from research institutions to farmers, and back to researchers and policy makers (Kyomo, 1992). Bridging the gap between research, extension and farmers is recognized as one of the most serious institutional problem for agricultural development. It is also recognized that an appropriate communication mechanism is a crucial component for improving transferability of technical information (Tollefson, 1995).

In view of the foregoing, there is a need for an improved and dynamic extension service provision that will enable farmers respond quickly to climate change and adeptly manage the associated risks. The public's increasing intolerance of climate change effects, coupled with its adverse impact on agricultural productivity indeed call for the development of a more efficient extension communication strategies and approaches. This study was therefore designed to assess the knowledge/awareness levels of extension agents and their perceived impact of climate change on extension delivery in Ghana.

\section{Aims and Objectives}

The aim of this study was to determine the knowledge levels of extension agents and their perceived demands/effects of climate change on extension service provision in Ghana.

The specific objectives of the study were to:

1. Identify the personal characteristics of the extension agents

2. Determine extension agents' knowledge of climate change

3. Ascertain the extension agents' perceived effects of climate change on extension service delivery

\section{Methodology}

A structured questionnaire was used to elicit information from a sample size of 192 respondents randomly selected from 10 regions in Ghana. The dependent variable for the study was knowledge of climate change by extension agents. A knowledge test of 49 items was conducted on climate change. It consists of 4 items on the causes, 32 items on the effects and 
13 items on mitigation. All the items were placed on 2 point Likert type scale of yes or no. Yes was assigned the score of 1 and no was scored zero for positive questions and vice versa for negative questions.Every repondent had the chance of a minimum score of zero and maximum of 49. Individual performance was converted to percentages with excellent $=70 \%$ and above, Good $=60-69 \%$, average $=50-59 \%$ and Poor $=49 \%$ and below. The independent variables include personal characteristics of agricultural extension agents and their perceived effects of climate change on extension provision. The personal characteristics include: age, gender, marital status, years of experience in extension service and location of residence. A 28 item scale of effects of climate change in providing extension service was placed on a three point Likert type scale of high $=3$, medium $=2$ and low $=1$. This was used to elicit information from the respondents and data was subjected to content analysis given the predominant use of Likert type scales. The data were further analyzed by using frequency, percentages, and mean.

\section{Results and Discussion}

A summary of personal characteristics of the respondents is presented in Table 1. It was shown that $0.5 \%$ of agricultural extension agents in the study are below 20 years of age, $13.6 \%$ were between the ages of 20-26 years, $24.6 \%$ were between ages 30-39 years, 31.9\% fell within 40-49 years while the remaining $28.9 \%$ were above 50 years. This implies that majority $(70.6 \%)$ of the extension agents are less than 50 years. It means that the greater part of the respondents are young and energetic and this is likely to positively influence their performance on the field. This also means that skills acquired through training and re-training programmes can still be utilized in the organization for at least 15 years or more. Still on the same table, a larger percentage (77.0\%) of the extension agents were found to be males while only $22.5 \%$ were females. This is an indication that extension service is dominated by men and this corroborates the observations of Saito and Weidemann (1990); Jiggins et al. (1998); Adomi et al. (2003); Hassan (2010); and $\mathrm{Rad}$ et al. (2011), that extension services have been staffed predominantly by men.

The working rank of the respondents sampled for the study showed that $7.9 \%$ were Technical Officer II (TO II), $11.0 \%$ in the rank of Technical Officer I (TO I), 18.3\% were in the rank of Senior Technical Officer (STO), 9.4\% in the rank of Principal Technical Officer and 13.6\% were Assistant Chief Tech Officers (ACTO) respectively. Furthermore, about 9.9\% were Chief Tech. Officer (CTO), $4.7 \%$ were Production Officer (PO). 3.1\% in the rank of Chief Production Officer (CPO), 8.4\%, 9.9\%, and $1.9 \%$ held the ranks of Assistant Agric. Officer (AAO), Agric. Officer (AO) and Senior Agric. Officer (SAO) respectively. This implies that more than half $(69.8 \%)$ of the respondents were in the technical rank. It can therefore be argued that they will be able to provide their clienteles with appropriate and relevant technical information, advice and training in order to improve their production or better still, cope with the impact of climate change. Similarly, Iwuchukwu and Onyeme (2013) found that extension agents were aware of the effects of climate change on natural resources such as agricultural produce.

Table 1: Distribution of respondent according to their socio-economics characteristics

\begin{tabular}{lll} 
Age of respondent & Frequency & Percentage $(\%)$ \\
\hline$<20$ & 1 & .5 \\
$20-29$ & 26 & 13.6 \\
$30-39$ & 47 & 24.6 \\
$40-49$ & 61 & 31.9 \\
$>50$ & 55 & 28.9 \\
Total & 190 & 99.5 \\
Marital Status & & \\
Single & 42 & 22 \\
Married & 148 & 77.5 \\
Total & 190 & 99.5 \\
Gender & & \\
Male & 147 & 77 \\
Female & 43 & 22.5
\end{tabular}


Working Rank

Technical Officer II (TO II) 15

Technical Officer I (TO I) 21

Senior Technical Officer (STO)

Principal Technical Officer

Assistant Chief Technical Officer (ACTO)

Chief Technical Officer (CTO)

Production Officer (PO)

Chief Production Officer (CPO)

Assistant Agric. Officer (AAO)

Agric. Officer (AO)

Senior Agric. Officer (SAO)

Total

13.6

Working Experience

$\leq 9$ years

34.4

$10-19$ years

$\geq 20$ years

35.6

27.9

Total

97.9

Specialization

Animal

17.8

Crop

42.9

Agric. economics

1.6

Agric. extension

24.6

Other

8.9

Total

95.8

Residential Address

Resident at point of duty

Non-resident at point of duty

Total

$190 \quad 99.5$

Additionally, $34.4 \%$ of the extension agents had a working experience of 10-19 years while $27.9 \%$ have been in service for more than 20 years. Majority of the respondents (42.9\%) were specialized in crop management practices. This implies that extension agents will be able to share with farmers their knowledge of cropping and management systems that are resilient to changing climate conditions (Davis, 2009). It was further shown that $17.8 \%$ of the respondents were specialized in animal production, $1.6 \%$ and $24.6 \%$ specialized in agricultural economics and agricultural extension. Only $8.9 \%$ of them specialized in other areas of agriculture. These attributes also suggests that different areas of specialization will assist their organization to effectively practice its unified system of extension. Many of the respondents (35.6\%) had working experience as extension agents for between 10 and 19 years. Some $(34.4 \%)$ had put in 9years and below while the rest $(27.9 \%)$ had been in the service for 20 years and above. The length of service is probably an indicator of a person's commitment to the chosen career (Ejembi et al., 2006). Frequent training and re-training programmes are needed to be put in place by an organization to strengthen this commitment. It also implies that most of the extension agents in the area were not new entrants in the service meaning that they must have had significant experience in climate change phenomenon. They would have also been aware of various adaptation strategies to cope with the impacts. This study also indicates that majority $(86.9 \%)$ of the respondents resided at the point of duty while the remaining $(12.9 \%)$ do not reside at point of duty.

Table 2 reveals the distribution of respondents according to their knowledge of climate change impact. The result shows that majority $(60.5 \%)$ of the respondents had excellent knowledge of climate change and its impact, $17.9 \%$ had a good knowledge of it, 9.5\% had an average knowledge while $12.1 \%$ had a poor knowledge of climate change impact. 
Knowledge Levels of Extension Agents and their Perceived Impact of Climate Change................ OGUNLADE et al.

Table 2: Distribution of respondents according to their knowledge of climate change

\begin{tabular}{lll}
\hline Level of Knowledge & Frequency & Percentage (\%) \\
\hline Excallent $(\geq 70 \%)$ & 115 & 60.5 \\
Good $(60-69 \%)$ & 34 & 17.9 \\
Average $(50-59 \%)$ & 18 & 9.5 \\
Poor $(\leq 49 \%)$ & 23 & 12.1 \\
\hline
\end{tabular}

The excellent knowledge of climate change by the majority of the respondents indicates that they have over the years acquired necessary information and awareness on the remote causes, effects and measures for climate change adaptation. This knowledge will go a long way in improving their competency skills in extension service provision especially on awareness creation and in the provision of appropriate techniques for managing climate change impact. It will also help in their discussions of the effects of climate change with the farmers during field days and training on the use of adaptive measures. It is opined that educators need to develop their own knowledge about climate change issues before they will be comfortable offering or preparing programs for their clients. This is also in agreement with Hersman (2004) who reported that the knowledge level of extension agents determines the amount of information the agents provided for their clientele.

Table 3 shows the distribution of respondents according to their Perceptions of impact/challenge of climate change on extension service provision. The table shows that the use of radio, community radio and FM stations for climate change extension messages and services ranked $1^{\text {st }}$, print media coverage of climate change impact ranked $2^{\text {nd }}$. Accessing appropriate and adequate information is critical in the process of enhancing the adaptive capacities of the rural areas to the impacts of

climate change. Information on weather or new technologies could be transmitted to the farmers using rural radio and other media and gatherings such as traditional ceremonies. The rapid development of mobile telephony is now opening up new opportunities and should be exploited fully to reach the otherwise remote and unreachable areas. Attitude toward coverage of climate change and increase in the extension research skills ranked $3^{\text {rd }}$ and $4^{\text {th }}$ respectively. The respondents' perception that 'extension message will have to address changing and diversified livelihood' ranked $5^{\text {th }}$ while perception that extension officers' knowledge level on climate change should change ranked $6^{\text {th }}$. The respondents perceptions that 'farmers require new skills ranked $7^{\text {th }}$, use of multimedia strategy ranked $8^{\text {th }}$ while extension officers require new skills and farmers need new training ranked $9^{\text {th }}$ and $10^{\text {th }}$ respectively. For extension message delivery on climate change, the respondents' perceptions that farmers need new training and also exposure to new technology both ranked $11^{\text {th }}$.This is especially true, as agriculture today needs to become professionalized with educational training incentives and development of human capital in the direction of crop and livestock production. There is need for effective capacity to strengthen the most vulnerable group in agricultural production with requisite knowledge and information necessary for climate change adaptation.

Table 3: Distribution of respondents according to their perceptions of impact/demand of climate change on extension service provision

\begin{tabular}{llll}
\hline Perceived impact of climate change on extension provisiondelivery & Mean & Std.Dev. & Rank \\
\hline Use of radio, community radio and FM stations for climate change & 2.66 & .50 & $1 \mathrm{st}$ \\
Print media coverage of climate change impact & 2.62 & .59 & $2 \mathrm{nd}$ \\
Attitude toward coverage of climate change impact & 2.61 & .60 & $3 \mathrm{rd}$ \\
Increase extension research skills & 2.58 & .57 & 4 th \\
Extension message will have to address changing and diversified livelihood & 2.56 & .59 & 5 th \\
Extension officers' knowledge level on climate change impact should change & 2.56 & .62 & 6 th \\
Farmers require new skills & 2.54 & .62 & 7 th \\
Use of multimedia strategy & 2.53 & .60 & 8 th \\
Extension officers require more information/awareness & 2.52 & .63 & 9 th \\
Farmers need new training in understanding climate change impact & 2.49 & .62 & 10 th \\
Farmers need exposure to new technology & 2.49 & .64 & 11 th \\
Extension officers need exposure to new technology & 2.49 & .64 & 11 th \\
\hline
\end{tabular}




\begin{tabular}{llll}
\hline Extension officers require new training on adaptation to climate change impact & 2.45 & .65 & 13th \\
Extension messages will have to address farmers' coping strategies for climate & 2.41 & .67 & 14th \\
change adaptation & & & \\
Extension messages will have to incorporate metereological information & 2.41 & .67 & 14th \\
Extension messages will have to address introduction of high yielding cultivars & 2.41 & .70 & 16th \\
Extension messages will have to address carbon sequestration practices & 2.40 & .68 & 17 th \\
Extension messages will have to address vulnerability to climate change & 2.40 & .72 & 18 th \\
Farmers require precision agriculture practices & 2.38 & .67 & 19 th \\
Proportion of weather information in extension messages will increase & 2.38 & .72 & 20 th \\
Extension services will change from generalise approach to specialist & 2.35 & .70 & 21 st \\
Farmer require new methods of coping with their livelihoods & 2.35 & .72 & 22nd \\
Extension messages will have to address early warning system & 2.35 & .73 & 23rd \\
Extension messages will have to address changing water use efficiency & 2.33 & .68 & 24 th \\
Extension messages will have to address changing inputs & 2.33 & .69 & 25 th \\
Farmers will need specialized and privatized extension services & 2.32 & .70 & 26th \\
Extension has to be abreast of innovations in agriculture & 2.27 & .68 & 27 th \\
Extension messages will have to address changing crop mix & 2.24 & .75 & 28th \\
\hline
\end{tabular}

The perceptions that extension officers need exposure to new technology and require training in adaptation to climate change impact ranked $11^{\text {th }}$ and $13^{\text {th }}$ respectively. The low levels of education/training of some extension officers adversely affect the quality of extension services (Belay and Abebaw 2004). To comprehend the impact of climate change and communicate the information, extension officers need regular training to upgrade their levels of information and awareness and should be able to advice and work together with smallholders on how to adapt to climate change impact. Their perceptions that extension messages will have to address farmers' coping strategies on climate change adaptation ranked 14th. In addition, their perception that extension messages will have to incorporate metereological information ranked $14^{\text {th }}$. This is in agreement with Sumner et al. (1998) who opined that major innovations in response to climate variability will take the form of improved information through global monitoring and weather forecasting. Perceptions that extension messages will have to address introduction of high yielding cultivars, extension messages will have to address carbon sequestration practices, extension messages will have to address vulnerability to climate change, farmers require precision agriculture practices, and proportion of weather information in extension messages will increase ranked $16^{\text {th }}, 17^{\text {th }}, 18^{\text {th }}, 19^{\text {th }}$ and $20^{\text {th }}$ respectively. Extension services should change from generalise approach to specialist ranked $21^{\text {st }}$ while farmer require new methods of coping with their livelihoods and the perception that extension messages will have to address early warning system ranked $22^{\text {nd }}$ and $23^{\text {rd }}$ respectively. Their perception that extension messages will have to address changing water use efficiency ranked $24^{\text {th }}$, while extension messages will have to address changing inputs ranked $25^{\text {th }}$. However, their perceptions that farmers will need specialized and privatized extension services, extension has to be abreast of innovations in agriculture and that extension messages will have to address changing crop mix ranked $26^{\text {th }}, 27^{\text {th }}$ and $28^{\text {th }}$ respectively. Although, extension agents are aware of these attributes, their perception based on the results implies that agents of change are not yet in tune with the pluralistic and bottom-up (participatory) extension service provision.

\section{Conclusion, Recommendations and Implications}

The study sought to ascertain the knowledge level and their perceived impact/demand of climate change on extension provision. From the findings, extension agents displayed a wide range of knowledge levels on climate change and in their perceptions of climate change impact on extension service delivery. The study confirmed that extension agents in the study area have high knowledge about climate change impact, its causes, effects and adaptation/mitigation methods. They perceived, among many others, the use of radio, community radio and FM stations for extension messages on climate change impact and adaptation. They recognized the need for a print media coverage of issues on climatic change and increasing the extension agents' research 
skills. The print media could also be a medium where farmers as well as the extension agents require new skills, training and exposure to new technology such as meteorological information that are capable of helping them to cope with the menace of climatic change.

Based on the findings and conclusion reached in this study, it is therefore recommended that agricultural extension agents should be trained and re-trained in information and knowledge acquisition in order to further enhance their climate change management skills. They should also make possible, the timely and effective dissemination of proven technologies to boost the adaptive/resilient capacities of various rural farmers to climate change issues. A more dynamic awareness programmes on the causes and consequences of climate change should also be in place. There is also a need for an increased research to make extension agents aware and understand the need to shift from technology transfer era to a more innovative, participatory and pluralistic approaches of extension service provision so as to adequately provide services to users of extension services (Klerkx et al., 2006). This will ensure more sustainable ways of adaptation to climate change.

\section{References}

Adomi, E. E., Ogbomo, M. O. and Inoni, O. (2003). Gender factor in crop farmers' access to agricultural information in rural areas of Delta State, Nigeria. Library Review, 52, 388-393.

Belay, K. and Abebaw, D. (2004) Challenges Facing Agricultural Extension Agents: A case from South-Western Ethiopia. Africa Development Review 16(1): 139 - 168.

Davis, K.E. (2009). Agriculture and Climate Change: An Agenda for Negotiation on Copenhagen "The Important Role of Extension Systems", International Food Policy Research Institute. Washington, D C.USA, Focus 16, Brief 11.

Dorward, A., Kydd, J., Morrison, J., and Urey, I. (2004). A policy agenda for pro-poor agricultural growth. World Development, 32(1), 73 - 89.

Ejembi, E.P., Omoregbee, F.E. and Ejembi, S.A. (2006). Farmers' assessment of the training and visit extension system in central Nigeria: Evidence from Barkin
Ladi, Plateau State. Journal of Social Sciences. 12 (3), pp. 207-212.

Hassan, M. (2010). Gender mainstreaming in agricultural extension: analysis and obstacles to gender mainstreaming in Agriculture Extension: a case study of district Muzaffargarh, Pakistan, Germany, VDM- Verlag Dr. Müller GmbH \& Co. KG Publisher.

Hersman, E.M. (2004). Knowledge and Dissemination of Sustainable Agriculture Practices by County Extension Agents in Ohio, Pennsylvania, and West Virginia. International Start Secretariat, Washington DC, USA.

Institute of Statistical Social and Economic Research (ISSER) (2007). Shared and inclusive growth in Ghana. Draft report prepared for the International Development, United Kingdom. ISSER, University of Ghana, Legon.

Iwuchukwu, J. and Onyeme, F. (2013). Awareness and perceptions of climate change among extension workers of Agricultural Development Programme (ADP) in Anambra State, Nigeria. Journal of Agricultural Extension, 16, 104-118.

Jiggins, J., Samanta, R. K. and Olawoye, J .E. (1998). Improving Women Farmers' Access to Extension Markets" American Journal of Agricultural Economics 80(5):1102-110.8

Klerkx, L., de Grip, K., and Leeuwis, C. (2006). Hands off but strings attached: the contradictions of policy-induced demanddriven agricultural extension. Agriculture and Human Values, 23(2), 189-204.

Kyomo, M. L. (1992). Importance of strong research-extension linkages in increasing livestock production in sub-Saharan Africa. In Kategile J A and Mubi S (editors). 1992. Future of livestock industries in East and southern Africa. Proceedings of a workshop held at Kadoma Ranch Hotel, Zimbabwe, 20-23 July 1992. ILCA (International Livestock Centre for Africa) Addis Ababa, Ethiopia. 227M pp. Available at: http://www.fao.org/Wairdocs/ILRI/x548 5E/x5485e06.htm

Leeuwis, C., and Aarts, N. (2011). Rethinking communication in innovation processes: 
creating space for change in complex systems. Journal of Agricultural Education and Extension, 17(1), 21-36.

Ministry of Environment of the Federal Republic of Nigeria (MoEFRN, 2003). Nigeria's First National Communication under the United Nations Framework Convention Nigeria. Journal of Agricultural Extension and Rural Development 3(3): 42-50,

Ozor, N., Madukwe, M. C., Enete, A. A., Amaechina, E. C., and Onokala, P. (2010). Barriers to climate change adaptation among farming households of Southern Nigeria. Journal of Agricultural Extension, 14(1).

Rad, S. T., Boz, İ., Polatöz, S. \& Ateş, H. Ç. (2011). Women's literacy and extension education in rural eastern Mediterranean Turkey. African Journal of Agricultural Research, 6, 2807-2819.

Saito, K. A. and Weidemann, C. J. (1990). Agricultural extension for women farmers in Africa, World Bank Publications.

Tollefson L.C. (1995): Requirements for improved interactive communication between researchers, managers, extensionists and farmers. Proceedings from the ICID/FAO workshop on Irrigation scheduling:
Tologbonse, E.B., Auta, S.J., Bidoli, T.D., Jaliya, M.M., Onu, R.O. and Issa, F.O. Watson, R.T., Zinyowera, M.C. Moses, R.H. (1997). The regional impacts of climate change: Western Ethiopia. Africa Development Review 16(1): 139 - 168.

Tologbonse, E. B., Auta, S. J., Bidoli, T. D., Jaliya, M. M., Onu, R. O., \& Issa, F. O. (2010). Farmers' Perception of the Effects of Climate Change and Coping Strategies in Three Agro-Ecological Zones of Nigeria. Journal of Agricultural Extension, 14(1).

United Nations Framework Convention on Climate Change (UNFCCC) (2007): Climate Change Impact, Vulnerabilities and Adaptation in Developing Countries. UNFCCC Secretariat, Martin-Luther King-Street, 853175 Bonn, Germany www.unfccc.int.

Ziervogel, G., Nyong, B., Osman, C., Conde, S.C. and Dowing, T. (2006). Climate variability and change: implications for household food security. Assessment of Impacts and Adaptations for Climate Change (AIACC) Working Paper No. 20, January 2006. The AIACC Project Office,

Zoellick, R.B. (2009). A climate smart future. The Nation Newspaper. Vintage on climate change. Abuja, Nigeria. 